\title{
Study the Impact of Age on Enzyme and Hormone Profile of Crossbred Calves
}

\author{
Milap G. Sedhiya ${ }^{1}$, M.M. Pathan ${ }^{1 *}$, A.M. Pande ${ }^{1}$, S.P. Madhira ${ }^{1}$, \\ R.J. Modi $^{2}$ and N.P. Sarvaiya ${ }^{3}$ \\ ${ }^{1}$ Department of Veterinary Physiology and Biochemistry, College of Veterinary Sci. \& A. H., \\ AAU, Anand, Gujarat, India \\ ${ }^{2}$ Department of Livestock Research Station, AAU, Anand, Gujarat, India \\ ${ }^{3} R B R U, A A U$, Anand, Gujarat, India \\ *Corresponding author
}

\begin{abstract}
A B S T R A C T
This study was conducted to evaluate the impact of age on serum enzymes and hormones in crossbred calves from birth to three months of age. The research was carried out on six apparently healthy crossbred calves (aged 0-3 months) with similar physiological status. Blood samples were collected from the experimental animals on $0,3,7,10,15,30,45,60$,

Keywords

Enzymes,

Hormones,

Crossbred calves

Article Info

Accepted:

10 April 2018

Available Online:

10 May 2018

75 and up to 90 days age of calves. Five $\mathrm{ml}$ of whole blood from each animal was collected in clot activator vacutainer. Serum was separated and analyzed for serum enzymes and hormones. The concentration of Alanine Transaminase and Aspartate Transaminase were significantly $(\mathrm{P}<0.05)$ highest on the day of birth while significantly $(\mathrm{P}<0.05)$ lowest concentration was observed on $90^{\text {th }}$ day of life. The serum Alkaline Phosphatase concentration was highest on the day of birth and decreased significantly ( $\mathrm{P}<$ $0.05)$ on $3^{\text {rd }}$ day. The serum Triiodothyronine $\left(\mathrm{T}_{3}\right)$ and Thyroxine $\left(\mathrm{T}_{4}\right)$ levels were significantly $(\mathrm{P}<0.05)$ highest on the day of birth. While the lowest concentration of $\mathrm{T}_{3}$ and $\mathrm{T}_{4}$ were observed on $90^{\text {th }}$ day of life. The level of $\mathrm{T}_{3}$ and $\mathrm{T}_{4}$ were decreasing significantly $(\mathrm{P}<0.05)$ from the day of birth to $90^{\text {th }}$ day of life. The non-significant difference was observed for serum cortisol from the day of birth to $90^{\text {th }}$ day of life in crossbred calf. It could be concluded that among obtained among enzymes, ALT, AST and AKP having significant variation. Triiodothyronine and throxine levels differed significantly while level of cortisol was not affected significantly during pre-weaning period of crossbred calf.
\end{abstract}

\section{Introduction}

The most vulnerable period in the life of any animal is the period after birth. In all species, the neonatal period represents a critical time during which all organ functions must adapt to the extra-uterine life; it is a transition phase from the sheltered intra-uterine to the exposed extra-uterine environment (Piccione et al., 2008). The increasing use of serum enzyme changes as aid to clinical diagnosis creates a need for understanding variations in serum enzymes in newborn animals. Marked temporary increase in serum activities of 
aspartate aminotransferase (AST) and alanine aminotransferase (ALT) in calves shortly after birth and reaching a maximum at 14 hours was observed (Maderova et al., 1963). These changes were attributed to absorption of enzymes from colostrum.

The thyroid is an endocrine gland that secrets mainly thyroxine hormone. Thyroid hormones are involved in the regulation of metabolic events of different components in various body tissues, growth, reproductive performance, development and adaptation in ruminant and other farm animals (Latimer et al., 2003; Todini, 2007). Many factors such as age, breed, nutrition, gender, season, climate and geographical traits of the region, the rearing technology, physiological conditions, method of measurement, drugs and disease affect the plasma concentrations of thyroid hormones (Todini, 2007; Stockham and Scott, 2002). These hormones circulate in blood bound to proteins, but small amounts of thyroid hormones are found in free form ( $\mathrm{fT}_{4}$ and $\mathrm{fT}_{3}$ ). Only the free hormone is responsible for the biological activity of thyroid hormones and available to tissues (Todini, 2007). The effect of age on plasma thyroid hormone was investigated in some farm animals. In most studies, the highest levels of thyroid hormones were reported during the first period of life, an advancement in age results in decreases of these hormone levels (Todini, 2007; Eshratkhah et al., 2010; Sharma et al., 1985). In most species, the percentage of $\mathrm{T}_{4}$ is higher than the other thyroid hormones in any period of life; with very little percentage of free forms of these hormones.

Pre-partum increase in fetal plasma Cortisol concentrations are also well documented for many mammalian species, including ruminants, and are related to adaptation of the neonate to extrauterine life (Hunter et al., 1977). Hence, the present study was planned in crossbred calves from birth to three months of age to find out the effect of age on enzymes and hormones.

\section{Materials and Methods}

The research was approved by the Institutional Animal Ethics Committee (IAEC, No.: 227/VPY/2016). The present study was conducted in the Department of Veterinary Physiology and Biochemistry, College of Veterinary Science \& A. H., Anand Agricultural University, Anand on crossbred calves maintained at Instructional Livestock Farm Complex (ILFC) of Department of Livestock Production Management at College of Veterinary Science \& A.H., Anand from birth to three months of age.

The experimental animals were reared in semi-open housing system which is made up of concrete floor under asbestos roofed housing system constructed east west direction and well covered with trees. These experimental calves were separated from other animals in pakka shed house. The experimental animals were maintained on ICAR feeding standards (1998).

Blood samples were collected from the experimental animals on $0,3,7,10,15,30$, $45,60,75$ and up to 90 days age of calves. Five $\mathrm{ml}$ of whole blood from each animal was collected aseptically from jugular vein from birth to three months of age in clot activator vacutainer. Serum was separated by centrifugation at $3000 \mathrm{rpm}$ for 15 minutes and stored at $-20{ }^{\circ} \mathrm{C}$ in deep freeze until analyzed for serum enzymes like alanine transaminase, aspartate transaminase alkaline phosphatase and hormones like triiodothyronine, thyroxine and cortisol.

The serum enzymes viz. alanine transaminase, aspartate transaminase, alkaline phosphatase and hormones like triiodothyronine, thyroxine and cortisol were analyzed using Diagnostic 
kits manufactured by Crest Biosystems, Coral Clinical Systems, Goa, by Spectrophotometer (model Visiscan 167). The serum hormonal parameters were analyzed at the Reproductive Biology Research Unit, College of Veterinary Science \& A.H., AAU, Anand, by RIA (Radio Immuno Assay) method using the kits manufactured by Immunotech, Beckmen Coulter, Czech Republic.

The data was analyzed using completely randomized design (CRD) and significance was tested by Duncan's New Multiple Range Test (DNMRT).

\section{Results and Discussion}

In the present experiment, the concentration of Alanine Transaminase and Aspartate Transaminase were significantly $(\mathrm{P}<0.05)$ highest on the day of birth $(39.32 \pm 1.95 \mathrm{U} / \mathrm{L}$ and $40.46 \pm 0.40 \mathrm{U} / \mathrm{L}$, respectively), while significantly $(\mathrm{P}<0.05)$ lowest concentration was observed on $90^{\text {th }}$ day $(12.98 \pm 0.14 \mathrm{U} / \mathrm{L}$ and $31.45 \pm 1.79 \mathrm{U} / \mathrm{L}$, respectively) of life. Both ALT and AST decreased significantly (P
$<0.05)$ from the day of birth to $90^{\text {th }}$ day of life with the mean value of $24.24 \pm 1.55 \mathrm{U} / \mathrm{L}$ and $35.11 \pm 1.64 \mathrm{U} / \mathrm{L}$, respectively. The serum Alkaline Phosphatase concentration was highest on the day of birth (656.21 \pm 53.20 $\mathrm{U} / \mathrm{L})$ and decreased significantly $(\mathrm{P}<0.05)$ on $3^{\text {rd }}$ day. The trend observed for the level of AKP was fluctuating up to $90^{\text {th }}$ day of life with the mean value of $489.38 \pm 25.01 \mathrm{U} / \mathrm{L}$ in crossbred calf. The data is depicted in Table 1.

The serum Triiodothyronine $\left(\mathrm{T}_{3}\right)$ and Thyroxine $\left(\mathrm{T}_{4}\right)$ levels were significantly $(\mathrm{P}<$ $0.05)$ highest on the day of birth $(3.38 \pm 0.39$ $\mathrm{ng} / \mathrm{ml}$ and $89.22 \pm 2.77 \mathrm{ng} / \mathrm{dl}$, respectively), while the lowest concentration of $\mathrm{T}_{3}$ and $\mathrm{T}_{4}$ were observed on $90^{\text {th }}$ day of life $(1.30 \pm 0.27$ $\mathrm{ng} / \mathrm{dl}$ and $38.11 \pm 0.33 \mathrm{ng} / \mathrm{dl}$, respectively). The level of $\mathrm{T}_{3}$ and $\mathrm{T}_{4}$ were decreasing significantly $(\mathrm{P}<0.05)$ from the day of birth to $90^{\text {th }}$ day of life with the mean value of 2.01 $\pm 0.35 \mathrm{ng} / \mathrm{dl}$ and $58.89 \pm 2.65 \mathrm{ng} / \mathrm{dl}$, respectively. The non-significant difference was observed for serum cortisol from the day of birth to $90^{\text {th }}$ day of life in crossbred calf. The data is depicted in Table 2.

Table.1 Mean $( \pm$ SEM) values of enzymes in crossbred calves $(n=6)$ from birth to 90 days

\begin{tabular}{|c|c|c|c|}
\hline Days & $\begin{array}{c}\text { Alanine } \\
\text { Transaminase (U/L) }\end{array}$ & $\begin{array}{c}\text { Aspartate } \\
\text { Transaminase (U/L) }\end{array}$ & $\begin{array}{c}\text { Alkaline } \\
\text { Phosphatase (U/L) }\end{array}$ \\
\hline 0 & $39.32^{\mathrm{a}} \pm 1.95$ & $40.46^{\mathrm{a}} \pm 0.40$ & $656.21^{\mathrm{a}} \pm 53.20$ \\
\hline 3 & $34.84^{\mathrm{ab}} \pm 2.21$ & $38.23^{\mathrm{ab}} \pm 1.42$ & $405.14^{b c} \pm 62.53$ \\
\hline 7 & $30.25^{b c} \pm 2.18$ & $37.01^{\mathrm{abc}} \pm 1.73$ & $487.46^{\mathrm{abc}} \pm 46.10$ \\
\hline 10 & $28.14^{c} \pm 2.17$ & $36.05^{\mathrm{abcd}} \pm 1.73$ & $457.32^{b c} \pm 72.37$ \\
\hline 15 & $25.16^{\mathrm{cd}} \pm 1.78$ & $35.08^{\mathrm{abcd}} \pm 1.73$ & $522.65^{a b c} \pm 39.81$ \\
\hline 30 & $22.24^{\mathrm{de}} \pm 1.37$ & $34.32^{\mathrm{bcd}} \pm 1.81$ & $483.33^{a b c} \pm 29.35$ \\
\hline 45 & $18.10^{\mathrm{ef}} \pm 0.45$ & $33.65^{\mathrm{bcd}} \pm 1.85$ & $565.49^{\mathrm{ab}} \pm 10.35$ \\
\hline 60 & $16.35^{\mathrm{fg}} \pm 0.51$ & $32.85^{\mathrm{bcd}} \pm 1.70$ & $447.98^{b c} \pm 64.53$ \\
\hline 75 & $15.02^{\mathrm{fg}} \pm 0.55$ & $31.96^{\mathrm{cd}} \pm 1.71$ & $487.15^{a b c} \pm 58.10$ \\
\hline 90 & $12.98^{\mathrm{g}} \pm 0.14$ & $31.45^{\mathrm{d}} \pm 1.79$ & $381.12^{c} \pm 50.54$ \\
\hline GM & $24.24 \pm 1.55$ & $35.11 \pm 1.64$ & $489.38 \pm 25.01$ \\
\hline $\mathrm{CV} \%$ & 15.69 & 11.46 & 25.88 \\
\hline $\mathrm{CD}_{0.05}$ & 4.415 & 4.672 & 146.95 \\
\hline
\end{tabular}

Values having different superscripts differed significantly $(\mathrm{P}<0.05)$ within column 
Table.2 Mean ( \pm SEM) values of hormones in crossbred calves $(n=6)$ from birth to 90 days

\begin{tabular}{|c|c|c|c|}
\hline Days & $\begin{array}{l}\text { Triiodothyronine } \\
\text { (ng/ml) }\end{array}$ & $\begin{array}{l}\text { Thyroxine } \\
\text { (ng/ml) }\end{array}$ & $\begin{array}{l}\text { Cortisol } \\
(\mathrm{ng} / \mathrm{ml})\end{array}$ \\
\hline 0 & $3.38^{\mathrm{a}} \pm 0.39$ & $89.22^{\mathrm{a}} \pm 2.77$ & $42.18^{\mathrm{ab}} \pm 10.89$ \\
\hline 3 & $2.04^{\mathrm{b}} \pm 0.43$ & $83.85^{\mathrm{ab}} \pm 1.69$ & $40.36^{\mathrm{ab}} \pm 9.77$ \\
\hline 7 & $1.61^{\mathrm{b}} \pm 0.32$ & $76.23^{b} \pm 1.27$ & $40.63^{\mathrm{ab}} \pm 7.97$ \\
\hline 10 & $1.79^{\mathrm{b}} \pm 0.33$ & $66.61^{c} \pm 4.50$ & $45.06^{\mathrm{ab}} \pm 8.94$ \\
\hline 15 & $2.13^{b} \pm 0.25$ & $58.99^{\mathrm{cd}} \pm 3.11$ & $37.47^{\mathrm{ab}} \pm 6.95$ \\
\hline 30 & $2.23^{\mathrm{ab}} \pm 0.13$ & $51.96^{\mathrm{d}} \pm 3.09$ & $33.49^{b} \pm 7.01$ \\
\hline 45 & $1.86^{\mathrm{b}} \pm 0.55$ & $42.45^{\mathrm{e}} \pm 2.74$ & $42.35^{\mathrm{ab}} \pm 7.83$ \\
\hline 60 & $2.31^{\mathrm{ab}} \pm 0.44$ & $41.28^{\mathrm{e}} \pm 1.27$ & $44.44^{\mathrm{ab}} \pm 7.75$ \\
\hline 75 & $1.45^{\mathrm{b}} \pm 0.23$ & $40.24^{\mathrm{e}} \pm 2.34$ & $53.09^{\mathrm{ab}} \pm 8.92$ \\
\hline 90 & $1.30^{\mathrm{b}} \pm 0.27$ & $38.11^{\mathrm{e}} \pm 0.33$ & $64.12^{\mathrm{a}} \pm 7.65$ \\
\hline GM & $2.01 \pm 0.35$ & $58.89 \pm 2.65$ & $44.32 \pm 8.45$ \\
\hline CV\% & 43.44 & 11.05 & 46.74 \\
\hline $\mathrm{CD}_{0.05}$ & 1.015 & 7.554 & \\
\hline
\end{tabular}

Values having different superscripts differed significantly $(\mathrm{P}<0.05)$ within column

Elevations in serum ALT is associated with reversible or irreversible damage to the hepatocyte plasma membrane.

Increased serum ALT activity has the highest sensitivity for inflammation, necrosis, vacuolar hepatopathy, and primary neoplasia.

Enzyme activity of AST transiently increased after colostrum intake but there was no association with time of first colostrum feeding, indicating that the rise of plasma AST activity was the consequence of enhanced endogenous production and was independent of colostrum intake (Zanker et al., 2001).

The higher level of AKP in serum of calf on the day of birth was most likely due to absorption of colostrum which causes activation of enzymes in the calf's intestine.

Thus, serum alkaline phosphatase appeared to be from intestinal sources and/or colostrum could be stimulating the intestinal alkaline phosphatase activity.
Based on these findings, it could be concluded that, enzymes viz. ALT, AST, AKP and hormones like triiodothyronine and throxine levels differed significantly while level of cortisol was not affected significantly during pre-weaning period of crossbred calf.

\section{References}

Eshratkhah, B., M. Sadaghian, S. Eshratkhah, S. Pourrabbi and Najafian, K. (2010) Relationship between the blood thyroid hormones and lipid profile in Moghani sheep; influence of age and sex. Comp. Clin. Path., 19(1): 15-20.

Hunter, J. T., Fairclough, R. J., Petersen, A. J. and Welch, R. A. S. (1977) Foetal and hormonal changes preceding normal bovine parturition. Acta Endocrinol, 84: 53-62.

Latimer, K. S., Mahaffy, E. A. and Prasse, K.W. (2003) Duncan and Prasse's Veterinary laboratory medicine, Clinical pathology (4th edition, pp. 280-291), Iowa state press, USA. 
Maderova, V., Neuman, V. and Kozumplik, F. (1963) Development of Serum Transaminase Activity in Very Young Calves. Sborn Vyz. Sk Zemeldeisk Bmo, 11: 187-188.

Piccione, G., Bertolucci, C., Giannetto, C. \& Giudice, E. (2008) Clotting profiles in newborn Maltese kids during the first week of life, J Vet Diagn. Invest, 20: 114-118.

Sharma, I. J., Agarwal, S. P., Agarwal, V. K. and Dwaraknath, P. K. (1985) Serum Thyroid Hormone Levels in Male Buffalo Calves as Related to Age and Sexual Development. Theriogenology, 24: 509-517.

Stockham, S. L. and Scott, M. A. (2002) Hemostasis. In S. L. Stockham and M.
A. Scott (Eds.), Fundamentals of Veterinary Clinical Pathology. (pp 155226), Lowa State Press, Ames, IA, USA.

Todini, L. (2007) Thyroid hormones in small ruminants: effects of endogenous, environmental and nutritional factors. Animal, 1(7): 997-1008.

Zanker, I. A., Hammon, H. M. and Blum, J. W. (2001) Activities of $\alpha$-glutamyl transferase, alkaline phosphatase and aspartate-aminotransferase in colostrum, milk and blood plasma of calves fed first colostrums at 0-2, 6-7, 12-13 and 24-25h after birth. J. Vet. Med. A., 48: 179-185.

\section{How to cite this article:}

Milap G. Sedhiya, M.M. Pathan, A.M. Pande, S.P. Madhira, R.J. Modi and Sarvaiya, N.P. 2018. Study the Impact of Age on Enzyme and Hormone Profile of Crossbred Calves. Int.J.Curr.Microbiol.App.Sci. 7(05): 912-916. doi: https://doi.org/10.20546/ijcmas.2018.705.111 